\title{
Control of Escherichia coli 0157:H7 in corn silage with or without various inoculants: Efficacy and mode of action
}

\author{
A. F. Pedroso, ${ }^{*} \dagger$ A. T. Adesogan, ${ }^{* 1}$ O. C. M. Queiroz, ${ }^{*}$ and S. K. Williams* \\ *Department of Animal Sciences, Institute of Food and Agricultural Sciences, University of Florida, Gainesville 32606 \\ †Brazilian Agricultural Research Corporation, Embrapa Cattle-Southeast, 13560-970 Sao Paolo, Brazil
}

\begin{abstract}
This study aimed to evaluate the effectiveness of 3 commercial bacterial inoculants at controlling Escherichia coli O157:H7 in corn silages during ensiling and feedout phases of silage production. A second objective was to determine whether the inoculants exhibited and transferred antibacterial activity against E. coli O157:H7 to the silages. Chopped corn forage was ensiled after treatment with the following: distilled water (control); $5 \times 10^{5} \mathrm{cfu} / \mathrm{g}$ of E. coli O157:H7 (EC); EC and $1 \times 10^{6} \mathrm{cfu} / \mathrm{g}$ of Pediococcus pentosaceus and Propionibacterium freudenreichii $(\mathrm{EC}+\mathrm{BII})$; $\mathrm{EC}$ and $1 \times$ $10^{6} \mathrm{cfu} / \mathrm{g}$ of Lactobacillus buchneri $(\mathrm{EC}+\mathrm{LB})$; and EC and $1 \times 10^{6} \mathrm{cfu} / \mathrm{g}$ of $L$. buchneri and P. pentosaceus $(\mathrm{EC}+\mathrm{B} 500)$. Each treatment was ensiled in triplicate in mini silos for 3, 7, 31, and $82 \mathrm{~d}$ and analyzed for $\mathrm{pH}$ and E. coli O157:H7 counts. Samples from d 82 were also analyzed for volatile fatty acids, lactate, and aerobic stability. Antibacterial activity of inoculants and silages was determined by the Kirby-Bauer disc diffusion test. The $\mathrm{pH}$ of silages from all treatments decreased below 4 within $3 \mathrm{~d}$ of ensiling and remained low until d 82 . Therefore, E. coli O157:H7 was not detected in silages after any of the ensiling durations. Applying inoculants containing L. buchneri resulted in less lactate, more acetate, and greater aerobic stability compared with the control. Applying EC+BII containing P. freudenreichii did not increase propionate or aerobic stability. Subsamples of d 82 silages were reinoculated with $1 \times 10^{5}$ cfu/g of E. coli O157:H7 either immediately after silo opening on d 82 or after $144 \mathrm{~h}$ of aerobic exposure (d 88), and E. coli were enumerated 24 h later. All silages reinoculated with the pathogen on d 82 had similar, low $\mathrm{pH}$ values $(<4)$ and no $E$. coli were detected $24 \mathrm{~h}$ later. Control, EC, and EC+BII silages reinoculated with the pathogen after $144 \mathrm{~h}$ of aerobic exposure had relatively greater $\mathrm{pH}$ values $(4.71,5.67$, and 6.03 , respectively) and E. coli counts $(2.87,6.73$, and $6.87 \mathrm{log}$
\end{abstract}

Received May 29, 2009.

Accepted November 4, 2009.

${ }^{1}$ Corresponding author: adesogan@animal.ufl.edu cfu/g, respectively) $24 \mathrm{~h}$ later, whereas those treated with $L$. buchneri had low $\mathrm{pH}$ values $(<4)$ and undetectable (EC+B500) or 10-fold lower (1.97, cfu/g; EC+LB) E. coli counts. All pure cultures of commercial bacterial inoculants exhibited antibacterial activity independent of $\mathrm{pH}$ against E. coli O157:H7, but the $\mathrm{pH}$-independent activity did not persist in the treated silages, suggesting that $E$. coli elimination from silages was mediated by $\mathrm{pH}$ reduction.

Key words: Escherichia coli O157:H7, bacterial inoculant, silage, antibacterial activity

\section{INTRODUCTION}

Escherichia coli O157:H7, a Shiga toxin-producing gram-negative bacteria, has emerged as an important cause of food borne disease since it was first isolated in 1982 (Riley et al., 1983). Cattle are the main reservoir of E. coli $\mathrm{O} 157: \mathrm{H} 7$ and the pathogen may be present in feces, milk, and feed of dairy cows (Chapman et al., 1997; Mechie et al., 1997; Lynn et al., 1998). Corn silage is one of the most widely used components of dairy cow rations and it can be contaminated with $E$. coli O157:H7 via manure or irrigation water (Weinberg et al., 2004). Escherichia coli O157:H7 was eliminated from ensiled, contaminated wheat and corn forage when the pH decreased below 5.0 (Chen et al., 2005). Elimination of the pathogen has been hastened by treatment with a bacterial inoculant that accelerated the $\mathrm{pH}$ decrease (Bach et al., 2002). Weinberg et al. (2004) also confirmed that ensiling is effective in eliminating $E$. coli spp. in contaminated forages but noted that these bacteria may develop in spoiled silages, which often have high $\mathrm{pH}$ levels. To date, no studies have examined whether bacterial inoculants that increase aerobic stability and maintain low $\mathrm{pH}$ after aerobic exposure such as Lactobacillus buchneri (Filya, 2003; Adesogan et al., 2003, 2004; Huisden et al., 2009) can also prevent the growth of E. coli on aerobically exposed silages.

Many lactic acid and propionic acid bacteria produce substances with antibacterial activity such as peroxides and bacteriocins (Jack et al., 1995; Meile et al., 1999). Gollop et al. (2005) reported that antibacterial activity independent of $\mathrm{pH}$ was present in many lactic acid 
bacteria inoculants but that the antibacterial activity was not imparted to some of the silages treated with the bacteria. Little is known about the antibacterial activity of bacterial silage inoculants against E. coli O157:H7.

The first objective of this study was to evaluate the effectiveness of bacterial inoculants containing homofermentative bacteria, heterofermentative bacteria, or both types of bacteria at controlling E. coli $\mathrm{O} 157: \mathrm{H} 7$ in corn silage during the anaerobic and aerobic stages of silage production. A second objective was to examine whether $\mathrm{pH}$-independent antibacterial activity against E. coli O157:H7 existed in the inoculants and persisted in inoculated silages.

\section{MATERIALS AND METHODS}

\section{Harvesting, Inoculation, and Ensiling}

The experiment was conducted at the Department of Animal Sciences, University of Florida (Gainesville) from October 2007 to July 2008. Corn forage was harvested at the $50 \%$ milk line stage $(30 \% \mathrm{DM})$ with a forage harvester (Claas Jaguar 900, Claas of America LLC, Columbus, IN) adjusted to achieve a 19-mm theoretical length of cut. The following treatments were applied in triplicate to the forage: distilled water (control); $5 \times$ $10^{5} \mathrm{cfu} / \mathrm{g}$ of E. coli O157:H7 (ATCC 43894; EC); EC and $1 \times 10^{6} \mathrm{cfu} / \mathrm{g}$ of Pediococcus pentosaceus 12455 and Propionibacterium freudenreichii $(\mathbf{E C}+\mathbf{B I I}) ; \mathrm{EC}$ and 1 $\times 10^{6} \mathrm{cfu} / \mathrm{g}$ of Lactobacillus buchneri $40788(\mathbf{E C}+\mathbf{L B})$; and EC and $1 \times 10^{6} \mathrm{cfu} / \mathrm{g}$ of L. buchneri 40788 and $P$. pentosaceus 12455 (EC+B500). The E. coli O157:H7 was supplied by $\mathrm{ABC}$ Research Corporation (Gainesville, FL), and bacteria in the $\mathrm{EC}+\mathrm{BII}, \mathrm{EC}+\mathrm{LB}$, and $\mathrm{EC}+\mathrm{B} 500$ treatments were from commercial inoculants (Biotal Plus II, Buchneri 40788, and Buchneri 500, respectively; Lallemand Animal Nutrition, Milwaukee, WI). The E. coli O157:H7 was grown in trypticase soy broth (Becton Dickinson Co., Franklin Lakes, NJ) for $24 \mathrm{~h}$ at $37^{\circ} \mathrm{C}$. Bacteria were sedimented by centrifugation $(3,000 \times g$ for $10 \mathrm{~min})$, washed 3 times, and resuspended in buffered peptone water (BPW; pH 7.2; Oxoid, Basingstoke, UK). Cells were adjusted to an optical density of 0.5 at $640 \mathrm{~nm}$ (Jasco V-530 Spectrophotometer, Jasco Inc., Easton, MD) to achieve $1 \times$ $10^{8} \mathrm{cfu} / \mathrm{mL}$ in the suspension (Bach et al., 2002). The population of $E$. coli in the suspension was verified by spread plating on sorbitol MacConkey agar (SMAC; Oxoid) supplemented with $0.05 \mathrm{mg} / \mathrm{L}$ cefixime and 2.5 $\mathrm{mg} / \mathrm{L}$ potassium tellurite (CT, Oxoid) to yield CTSMAC. Suspensions of the pathogen were diluted in distilled water and applied to achieve $5 \times 10^{5} \mathrm{cfu} / \mathrm{g}$ at ensiling. The commercial inoculants were suspended in distilled water and applied at the rate of $3 \mathrm{~mL} / \mathrm{kg}$ of fresh forage to achieve $1 \times 10^{6} \mathrm{cfu} / \mathrm{g}$ in the forage, and the same amount of distilled water was applied to the control. The number of bacteria in the commercial inoculants was previously determined by serial dilutions in BPW, spread plating in de Man, Rogosa, Sharpe (MRS) agar (Difco, Detroit, MI), and incubating for $24 \mathrm{~h}$ at $35^{\circ} \mathrm{C}$.

The forage for each treatment $(25 \mathrm{~kg})$ was spread onto a plastic sheet and the treatment was applied using a manual sprayer. Afterward, the 4 ends of the plastic sheet were drawn together and the forage was tumbled for $3 \mathrm{~min}$ to ensure even distribution of the inoculum. Approximately $1.5 \mathrm{~kg}$ of forage from each treatment was manually compacted into a $14 \times 21-\mathrm{cm}$, thick-walled plastic bag. Each treatment was prepared in triplicate and ensiled for 3,7 , or $31 \mathrm{~d}$ at $20^{\circ} \mathrm{C}$ to give a total of 45 bag silos. Samples from these bags were used to determine changes in E. coli O157:H7 counts and $\mathrm{pH}$ over time. In addition, $4.5 \mathrm{~kg}$ of forage from each treatment were manually compacted in triplicate into 20-L mini silos lined with thick-walled plastic bags and ensiled for $82 \mathrm{~d}$ at $20^{\circ} \mathrm{C}$ at an approximate density of $500 \mathrm{~kg} / \mathrm{m}^{3}$. On d 82 , these mini silos were opened and their contents were mixed thoroughly and representatively subsampled for analysis of $\mathrm{pH}$, lactate, VFA, aerobic stability, and E. coli O157:H7, yeast, and mold enumeration. Additional samples were also taken for reinoculation with $E$. coli.

\section{Aerobic Stability}

Approximately $1.3 \mathrm{~kg}$ of d 82 silage from each treatment replicate was transferred to a plastic bag within an open-top foam container. Silage boxes were covered with 2 layers of cheese cloth to avoid dehydration and stored at $20^{\circ} \mathrm{C}$ for $144 \mathrm{~h}$. Silage temperature was monitored with thermocouples (Campbell Scientific Inc., Logan, $\mathrm{UT}$ ) placed in the geometrical center of the silage mass in each box. Thermocouples were connected to a data logger (CR 1000 data logger; Campbell Scientific Inc.) that recorded silage temperatures at 30-min intervals. Aerobic stability was defined as the number of hours the temperature in the silages remained stable before rising more than $2^{\circ} \mathrm{C}$ above room temperature.

\section{Survival of E. coli 0157:H7 in Silages Exposed to Aerobic Conditions}

This aspect of the experiment determined whether treatment with the commercial inoculants at ensiling would prevent the growth of E. coli $\mathrm{O} 157: \mathrm{H} 7$ in silages contaminated with the pathogen after silos were opened. Approximately $1 \mathrm{~kg}$ of silages sampled at silo opening 
and those aerated for $144 \mathrm{~h}$ in the aerobic stability assay were transferred into separate plastic bags and reinoculated with $1 \times 10^{5} \mathrm{cfu} / \mathrm{g}$ of $E$. coli O157:H7. Silage $\mathrm{pH}$ and $E$. coli counts were determined $24 \mathrm{~h}$ after reinoculation.

\section{Laboratory Analyses}

Silage extracts for enumeration of E. coli, analysis of VFA, $\mathrm{pH}$, and determination of antibacterial activity in the silages were prepared by blending $15 \mathrm{~g}$ of silage and $135 \mathrm{~mL}$ of distilled water in a stomacher (UL LabBlender 400, Seward Laboratory, London, UK) for 2 min. For VFA determination, the extracts were filtered through 2 layers of cheese cloth and frozen $\left(-10^{\circ} \mathrm{C}\right)$ after addition of $3 \mathrm{~mL}$ of $50 \%$ sulfuric acid per $100 \mathrm{~mL}$ of extract. The extracts for enumeration of yeasts and molds were prepared by blending $25 \mathrm{~g}$ of silage with 225 $\mathrm{mL}$ of distilled water for $2 \mathrm{~min}$ in the stomacher.

Microbial Enumeration. For enumeration of $E$. coli $\mathrm{O} 157: \mathrm{H} 7$ in the suspensions prepared to inoculate silages and in silage extracts, serial 10-fold dilutions were prepared in BPW followed by spread plating on CT-SMAC agar. Plates were incubated for $24 \mathrm{~h}$ at $35^{\circ} \mathrm{C}$. Colonies on CT-SMAC were screened by API-20E System (BioMerieux Inc., Hazelwood, MO) and confirmed as E. coli $\mathrm{O} 157: \mathrm{H} 7$ by latex agglutination using $\mathrm{O} 157$ and $\mathrm{H} 7$ antisera (Difco). The number of bacteria in suspensions of commercial inoculants was determined by serial dilutions in BPW and spread plating on MRS agar. Plates were incubated for $24 \mathrm{~h}$ at $35^{\circ} \mathrm{C}$. For yeast and mold enumeration, silage extracts were serial diluted in BPW and spread plated on Rose Bengal agar (Oxoid) supplemented with $1.0 \mathrm{~mL} / \mathrm{L}$ dichloran $0.2 \%$ in ethanol (Ultra Scientific, Kingstown, RI) and $0.1 \mathrm{~g} / \mathrm{L}$ of chloramphenicol (Fisher Biotech, Fair Lawn, NJ). Plates were incubated for $5 \mathrm{~d}$ at $27^{\circ} \mathrm{C}$. For all microbial counts, a range of dilutions was prepared in duplicate and plates yielding 30 to 300 colonies were counted.

Chemical Analysis. The DM content in the initial forage and silages was determined by drying samples in a forced-air oven at $55^{\circ} \mathrm{C}$ for $48 \mathrm{~h}$. The $\mathrm{pH}$ of silage extracts was measured using a digital $\mathrm{pH}$ meter (Accumet AB15, Fisher Scientific). Lactate and VFA concentrations were analyzed by HPLC as described by Muck and Dickerson (1988).

Antibacterial Activity. Antibacterial activity against E. coli $\mathrm{O} 157: \mathrm{H} 7$ in pure cultures of the inoculants and d 82 silage extracts was determined by the Kirby-Bauer disc diffusion test. Petri plates containing $1 \%$ of the E. coli $\mathrm{O} 157: \mathrm{H} 7$ inoculum $\left(10^{8} \mathrm{cfu} / \mathrm{mL}\right)$ were prepared on CT-SMAC agar. Bacteria in the commercial inoculants were grown in MRS broth at $35^{\circ} \mathrm{C}$ for 24 h. Cell-free supernatants were prepared by centrifuging the cultures at $3,000 \times g$ for $10 \mathrm{~min}$ at $5^{\circ} \mathrm{C}$. The $\mathrm{pH}$ of the supernatants was adjusted to 5.0 with $2 \mathrm{~N} \mathrm{NaOH}$. Silage extracts were similarly centrifuged and the cellfree supernatants were adjusted to $\mathrm{pH} 5$. Two paper discs (6-mm diameter; cat. no. 231039, Becton Dickinson Co.) were immersed in the supernatants for 15 s using flame-sterilized forceps and then placed on the surface of CT-SMAC agar plates containing the indicator microorganism. Plates were prepared in duplicate and incubated for $24 \mathrm{~h}$ at $35^{\circ} \mathrm{C}$. Zones of inhibition around the paper discs were measured with a ruler.

\section{Statistical Analysis}

The experiment had a completely randomized design with 5 treatments and 3 replicates per treatment. Data were analyzed with the General Linear Model procedure of SAS (SAS Institute Inc., Cary, NC) and a model including the treatment effect. In addition, the model used for analyzing changes in $\mathrm{pH}$ and $E$. coli during ensiling included time and treatment $\times$ time. Differences between means were determined using the Tukey test. Significant differences were declared if $P<0.05$.

\section{RESULTS}

\section{Anaerobic Phase}

The $\mathrm{pH}$ of all silages decreased to values below 4 within $3 \mathrm{~d}$ of ensiling and remained low at all subsequent ensiling durations (Figure 1). The $\mathrm{pH}$ at final silo opening $(\mathrm{d} 82)$ was greater $(P<0.05)$ in silages treated with commercial inoculants (3.72) than in control and EC silages (3.52). Escherichia coli was not detected in silages after any of the ensiling durations.

Silages treated with inoculants containing $L$. buchneri $(\mathrm{EC}+\mathrm{LB}$ and $\mathrm{EC}+\mathrm{B} 500)$ had lower lactate and greater acetate concentrations than other treatments (Table 1). The EC+LB silage had less $(P<0.05) \mathrm{DM}$ than control, EC, and EC+BII silages. Propionate and butyrate concentrations were low or undetectable in all silages. Applying the inoculant containing propionic bacteria (EC+BII) did not result in greater propionic acid concentration compared with other treatments.

\section{Aerobic Phase}

Yeasts and molds were not detected in silages treated with $L$. buchneri inoculants but they were present in other silages. Treatment with L. buchneri inoculants improved aerobic stability by at least $115 \%$ compared with the control, but treatment with $\mathrm{EC}$ or EC+BII did not affect aerobic stability (Figure 2).

Escherichia coli O157:H7 was not detected in silages reinoculated with the pathogen at final silo opening (d 


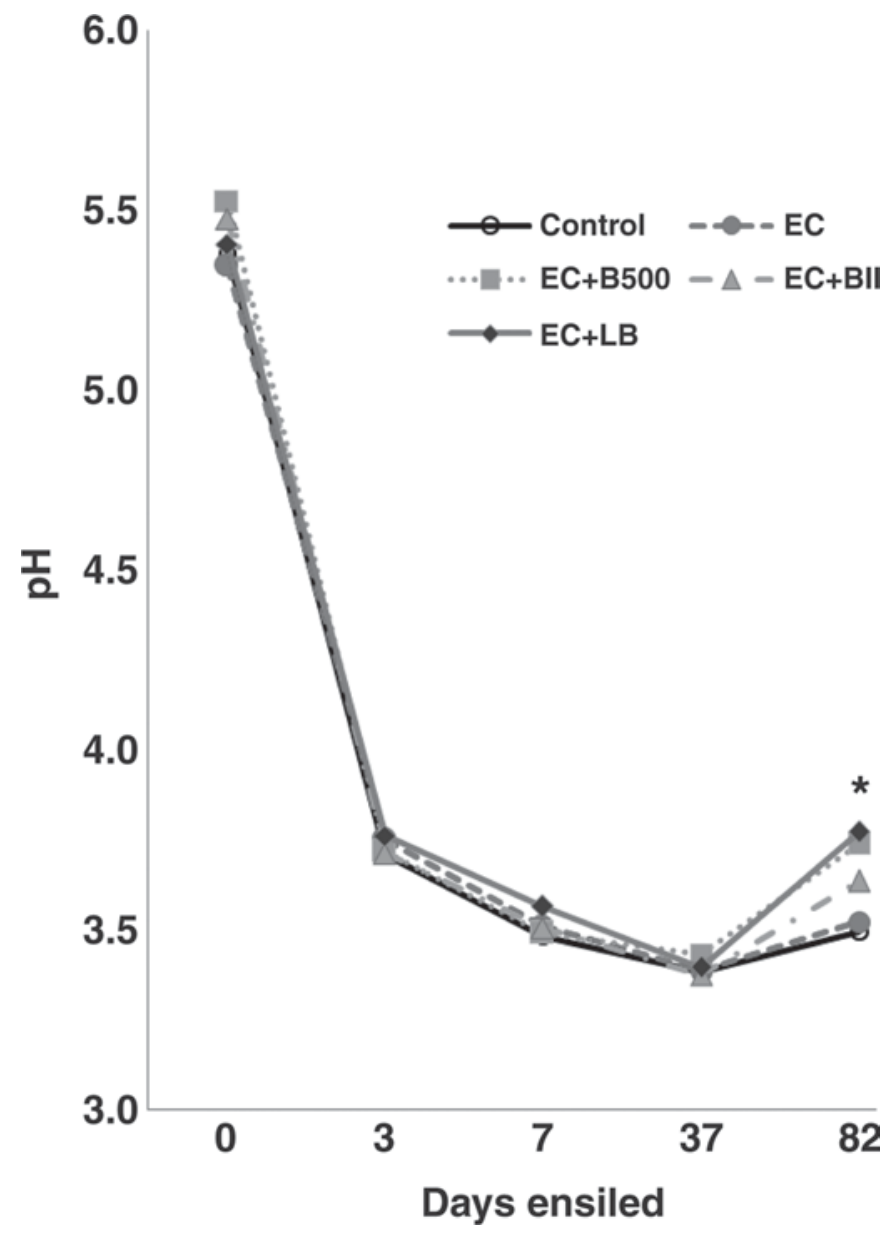

Figure 1. Changes in $\mathrm{pH}$ in corn forage inoculated with $5 \times 10^{5} \mathrm{log}$ $\mathrm{cfu} / \mathrm{g}$ of Escherichia coli O157:H7 (EC) or EC plus bacterial inoculants and ensiled for different durations $(\mathrm{BII}=$ Pediococcus pentosaceus + Propionibacterium freudenreichii; $\mathrm{LB}=$ Lactobacillus buchneri; $\mathrm{B} 500=$ $P$. pentosaceus $+L$. buchneri). Treatment $\times$ day SE and $P$-value for $\mathrm{pH}=0.33$ and 1.00 , respectively; ${ }^{*} \mathrm{pH}$ values differed at this ensiling duration.

82) and exposed to the air for $24 \mathrm{~h}$, probably because $\mathrm{pH}$ remained below 4 in all silages during that period $($ mean $=3.78 \pm 0.13)$. However, the pathogen was present in all silages reinoculated $144 \mathrm{~h}$ after silo opening except in the silage treated with EC+B500 (Figure 3). One day after reinoculation, control, EC, and EC+BII silages had relatively high $\mathrm{pH}$ values $(4.71,5.67$, and 6.03 , respectively) and $E$. coli counts $(2.87,6.73$, and $6.87 \log \mathrm{cfu} / \mathrm{g}$, respectively; $P<0.05$ ), whereas those treated with $L$. buchneri inoculants had low $\mathrm{pH}$ values $(<4)$ and undetectable $(\mathrm{EC}+\mathrm{B} 500)$ or low $(1.97, \mathrm{cfu} / \mathrm{g}$; $\mathrm{EC}+\mathrm{LB})$ E. coli counts. Counts of the pathogen were at least 10-fold less in silages treated with L. buchneri inoculants compared with other treatments.

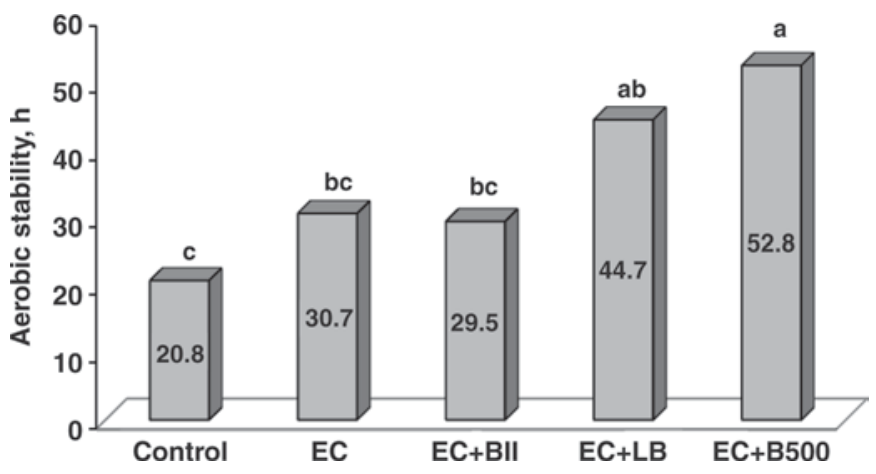

Figure 2. Effect of inoculation with $5 \times 10^{5} \mathrm{cfu} / \mathrm{g}$ of Escherichia coli O157:H7 (EC) or EC and bacterial inoculants at ensiling on aerobic stability of corn silages ensiled for $82 \mathrm{~d}(\mathrm{BII}=$ Pediococcus pentosaceus + Propionibacterium freudenreichii $; \mathrm{LB}=$ Lactobacillus buchneri; $\mathrm{B} 500=P$. pentosaceus + L. buchneri $)$. Bars with different letters differed $(P<0.05) ; \mathrm{SE}=4.11$.

\section{Antibacterial Activity}

The $\mathrm{pH}$-corrected cell-free supernatants from pure cultures of each commercial inoculant produced a 2.5$\mathrm{mm}$ zone of inhibition against $E$. coli $\mathrm{O} 157: \mathrm{H} 7$, whereas no zone was evident from that of the control. In addition, no inhibition zone against the pathogen was produced by cell-free supernatants from extracts of $\mathrm{d}$ 82 silages treated with these inoculants.

\section{DISCUSSION}

The fact that $E$. coli $\mathrm{O} 157: \mathrm{H} 7$ was undetected in silages during the anaerobic phase is most probably attributable to the inhibitory low $\mathrm{pH}$ resulting from formation of fermentation acids during ensilage. A bacterial inoculant that accelerated the rate of lactate accumulation and the resulting $\mathrm{pH}$ decrease reduced ( 7 vs. 15 d) the period required for elimination of $E$. coli O157:H7 from barley silage contaminated with the pathogen (Bach et al., 2002). In this study, as in others on corn and grass silage (Byrne et al., 2002; Chen et al., 2005), E. coli was eliminated during ensiling even in the absence of inoculation because a low $\mathrm{pH}$ was rapidly achieved.

Inoculants containing L. buchneri have improved the aerobic stability of different silages (Driehuis et al., 2001; Weinberg et al., 2002; Kleinschmit et al., 2005). In this study, inoculation with L. buchneri inoculants increased the aerobic stability of corn silage by at least $115 \%$. This effect is attributable to the inhibitory effect of acetate produced by L. buchneri on spoilagecausing fungi (Driehuis et al., 2001; Ranjit et al., 2002). Yeasts are controlled by acetic acid levels above 5.6 
Table 1. Dry matter, organic acids, and yeast and mold values of corn forage inoculated with Escherichia coli O157:H7 (EC) alone or EC and commercial bacterial inoculants and ensiled for $82 \mathrm{~d}$

\begin{tabular}{lcccccc}
\hline & \multicolumn{5}{c}{ Treatment $^{1}$} \\
\cline { 2 - 5 } Attribute & Control & EC & EC + BII & EC + LB & EC + B500 & SE \\
\hline DM (\%) & $26.3^{\mathrm{ab}}$ & $26.6^{\mathrm{ab}}$ & $27.1^{\mathrm{a}}$ & $25.0^{\mathrm{c}}$ & $25.8^{\mathrm{bc}}$ & 0.34 \\
Lactate (\% of DM) & $2.69^{\mathrm{a}}$ & $2.10^{\mathrm{a}}$ & $2.12^{\mathrm{a}}$ & $0.48^{\mathrm{b}}$ & $1.10^{\mathrm{b}}$ & 0.31 \\
Acetate (\% of DM) & $2.42^{\mathrm{c}}$ & $1.73^{\mathrm{c}}$ & $1.98^{\mathrm{c}}$ & $4.77^{\mathrm{a}}$ & $3.81^{\mathrm{b}}$ & 0.35 \\
Propionate (\% of DM) & 0.26 & 0.00 & 0.00 & 0.00 & 0.01 & 0.2 \\
Butyrate (\% of DM) & 0.21 & 0.00 & 0.00 & 0.00 & 0.00 & 0.11 \\
Yeasts and molds (log cfu/g) & $2.13^{\mathrm{ab}}$ & $5.67^{\mathrm{a}}$ & $6.30^{\mathrm{a}}$ & $0.00^{\mathrm{b}}$ & $0.00^{\mathrm{b}}$ & 1.7 \\
\hline
\end{tabular}

${ }^{\mathrm{a}-\mathrm{c}}$ Means within a row with different superscripts differ $(P<0.05)$.

${ }^{1}$ Control $=$ distilled water $\mathrm{EC}=5 \times 10^{5} \mathrm{cfu} / \mathrm{g}$ of Escherichia coli $\mathrm{O} 157 \mathrm{H7} ; \mathrm{BII}=1 \times 10^{6} \mathrm{cfu} / \mathrm{g}$ of Pediococcus pentosaceus and Propionibacterium freudenreichii; $\mathrm{LB}=1 \times 10^{6} \mathrm{cfu} / \mathrm{g}$ of Lactobacillus buchneri; $\mathrm{B} 500=1 \times$ $10^{6} \mathrm{cfu} / \mathrm{g}$ of Pediococcus pentosaceus and Lactobacillus buchneri.

$\mathrm{g} / \mathrm{L}$ of culture medium (Woolford, 1975). As in this study, inoculation with $L$. buchneri typically results in acetate concentrations ranging from 36 to $50 \mathrm{~g} / \mathrm{kg}$ of DM (Driehuis et al., 2001; Taylor et al., 2002).

Propionic acid is the most effective antimycotic agent among short-chain fatty acids at $\mathrm{pH} 5$ or lower (Woolford, 1975); therefore, inoculants containing propionic acid bacteria have been tested for their ability to improve aerobic stability. Merry and Davies (1999) indicated that such bacteria have not consistently inhibited the growth of yeasts and molds or improved aerobic stability because they do not grow well when ensiling conditions are conducive to a rapid decrease in $\mathrm{pH}$. Previous studies showed that inoculation with $P$. freudenreichii $\left(1 \times 10^{4} \mathrm{cfu} / \mathrm{g}\right)$ with or without homolac- tic bacteria did not affect propionic acid concentration, yeast and mold counts, or aerobic stability of maize and barley silages (Ranjit et al., 2002; Taylor et al., 2002). Likewise, treatment with the inoculant containing $P$. pentosaceus and $P$. freudenreichii did not affect these measures in this study.

Although antibacterial activity against E. coli was evident in cultures of the commercial inoculants, it was not detected in silages treated with the inoculants. Gollop et al. (2005) also showed that pure cultures of different strains of $L$ plantarum, Enterococcus faecium, and L. buchneri inhibited the growth of Micrococus luteus and Pseudomonas aeruginosa, but only some of the extracts of silages treated with these bacteria had antibacterial activity independent of $\mathrm{pH}$. Antibacterial

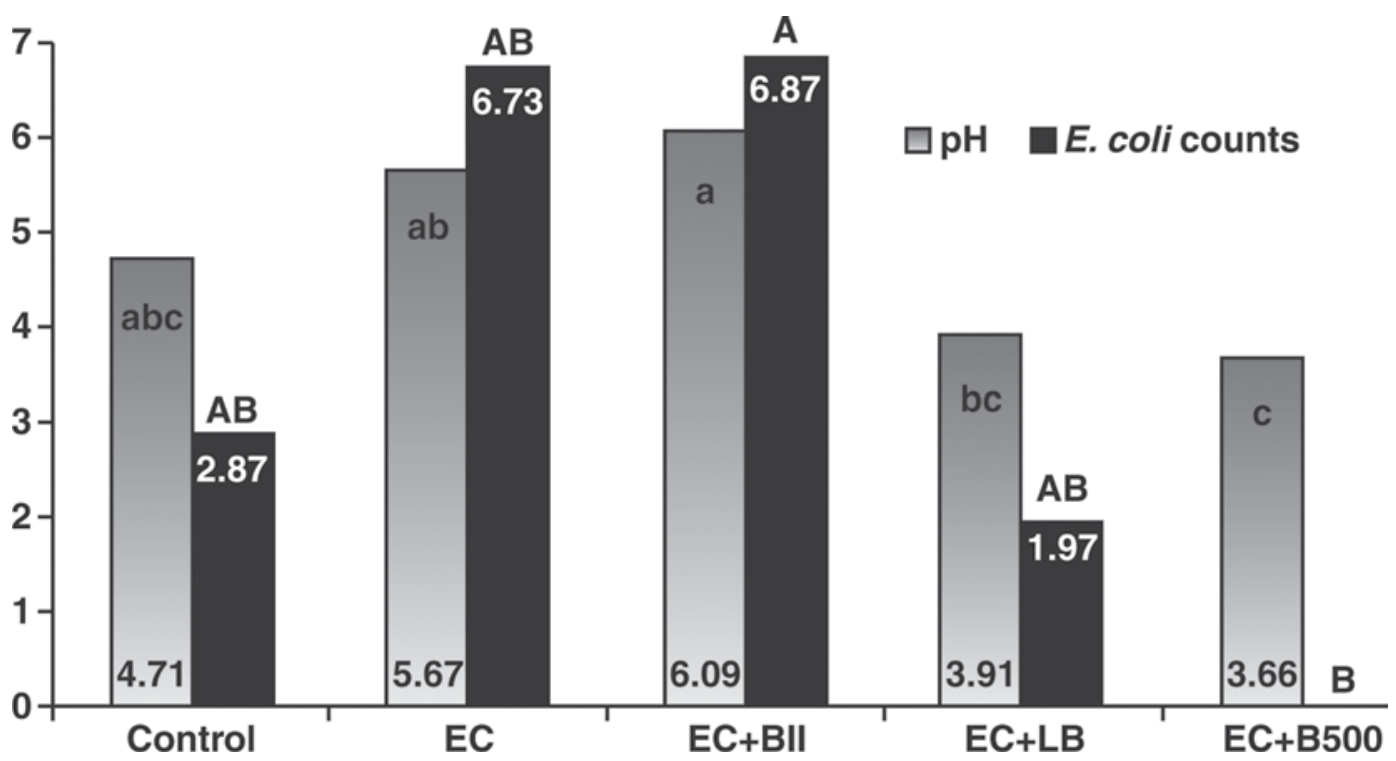

Figure 3. Effect of reinoculation of corn silages with $1 \times 10^{6} \mathrm{cfu} / \mathrm{g}$ of Escherichia coli O157:H7 (EC) $144 \mathrm{~h}$ after silo opening (d 82) on $\mathrm{pH}$ and E. coli counts $(\log \mathrm{cfu} / \mathrm{g})$ of silages treated with $\mathrm{EC}$ or $\mathrm{EC}$ and bacterial inoculants at ensiling $(\mathrm{BII}=$ Pediococcus pentosaceus + Propionibacterium freudenreichii; $\mathrm{LB}=$ Lactobacillus buchneri; $\mathrm{B} 500=$ P. pentosaceus + L. buchneri). Similarly shaded bars with different letters differed $(P<0.05)$; SE values for $\mathrm{pH}$ and $E$. coli data were 0.41 and 1.04 , respectively. 
activity is dependent on several factors, including water activity, $\mathrm{pH}$, temperature, and VFA concentration, and it varied with crop species and crop moisture concentration in the study of Gollop et al. (2005). The antibacterial activity of inoculant bacteria can be exploited to enhance forage preservation and food safety; therefore, future work should determine the source of such activity in silage inoculants and devise methods to ensure its persistence against spoilage-causing or pathogenic microorganisms in silages.

Fenlon and Wilson (2000) reported that E. coli O157:H7 numbers in poorly fermented, artificially inoculated silages grew from $10^{3}$ to $10^{6} \mathrm{log} \mathrm{cfu} / \mathrm{g}$ during the first $7 \mathrm{~d}$ of ensilage when the $\mathrm{pH}$ stayed above 5 . Similarly, in this study, E. coli counts in samples reinoculated with the pathogen after $144 \mathrm{~h}$ of aerobic exposure increased from $10^{5}$ to more than $10^{6} \mathrm{cfu} / \mathrm{g}$ when the $\mathrm{pH}$ was above 5. Weinberg et al. (2004) showed that though low $\mathrm{pH}$ achieved during ensilage eliminates $E$. coli from contaminated forages, the pathogen can be found in decaying parts of commercial silages with high $\mathrm{pH}$. In agreement, in this study, E. coli was undetected in silages when $\mathrm{pH}$ was less than 4 during ensiling. Furthermore, growth of $E$. coli in silages reinoculated with the pathogen after $144 \mathrm{~h}$ of aerobic exposure depended on $\mathrm{pH}$. High populations were present in control, EC, and EC+BII silages, which had high $\mathrm{pH}(>4)$, whereas they were at least about 10 -fold lower in silages treated with L. buchneri inoculants, which had $\mathrm{pH}$ greater than 4 . These results indicate that preventing aerobic deterioration and the attendant $\mathrm{pH}$ increase can prevent or minimize the growth of E. coli O157:H7 in silages contaminated with the pathogen during the feedout phase.

Maintenance of the low $\mathrm{pH}$ achieved at silo opening for $144 \mathrm{~h}$ by inoculants containing L. buchneri is probably attributable to the inhibitory effect of the acetate produced by L. buchneri on yeasts that metabolize lactate and thereby increase the $\mathrm{pH}$ in aerobically exposed silages. Our data suggest that L. buchneri inoculants can be used to maintain low $\mathrm{pH}(<4)$ in silages during the feedout phase and thereby curtail the growth of E. coli O157:H7 from extraneous sources that might contaminate the forage.

The E. coli strain used in this experiment (ATCC 43894) was reported to have low acid tolerance (Benjamin and Datta, 1995), indicating its susceptibility to inhibition during acidic silage fermentation. However, E. coli O157:H7 may acquire acid tolerance, and acid-tolerant strains could conceivably survive the low $\mathrm{pH}$ achieved in silages. Nevertheless, all studies we reviewed on the subject indicate that the ensiling process in well-managed silages is efficient at eliminating $E$. coli O157:H7 (Bach et al., 2002; Byrne et al., 2002; Chen et al., 2005). Future work should examine whether other factors such as bacteriocins, competition with other microorganisms, and high organic acid concentrations contribute to elimination of the pathogen when forages are ensiled.

\section{CONCLUSIONS}

This study shows that E. coli O157:H7 was eliminated from forages contaminated with $5 \mathrm{log} \mathrm{cfu} / \mathrm{g}$ of the pathogen when the $\mathrm{pH}$ dropped to 4 within $3 \mathrm{~d}$ of ensiling. Inoculant treatment did not affect $E$. coli O157:H7 elimination during ensiling but, unlike other treatments, application of L. buchneri inoculants eliminated yeast and mold populations, increased aerobic stability, and kept the $\mathrm{pH}$ below 4 for the duration of the 144-h aerobic exposure period. Reinoculation of silages with $E$. coli $\mathrm{O} 157: \mathrm{H} 7$ after $144 \mathrm{~h}$ of aerobic exposure resulted in relatively high $(P>0.05) E$. coli O157:H7 counts of $2.87,6.73$, and $6.87 \mathrm{cfu} / \mathrm{g}$ for the control, EC, and EC+BII silages, respectively, whereas counts in EC+LB silages (1.96 log cfu/g) were low and the pathogen was not detected in EC+B500 silages. This suggests that L. buchneri inoculants can be used to curtail the growth of $E$. coli in silages contaminated with the pathogen at the feedout stage. All pure cultures of commercial bacterial inoculants exhibited antibacterial activity independent of $\mathrm{pH}$ against $E$. coli $\mathrm{O} 157: \mathrm{H} 7$, but the activity did not persist in the treated silages, suggesting that E. coli O157:H7 elimination from the silages was mediated by $\mathrm{pH}$ reduction.

\section{ACKNOWLEDGMENTS}

We gratefully acknowledge funding for this study from Lallemand Animal Nutrition, Milwaukee, Wisconsin, and the postdoctoral fellowship granted to A. F. Pedroso by Coordenação de Aperfeiçoamento de Pessoal de Nível (CAPES), Brasília, Brazil.

\section{REFERENCES}

Adesogan, A. T., N. A. Krueger, M. B. Salawu, D. B. Dean, and C. R. Staples. 2004. The influence of treatment with dual purpose inoculants or soluble carbohydrates on the fermentation and aerobic stability of bermudagrass. J. Dairy Sci. 87:3407-3416.

Adesogan, A. T., M. B. Salawu, A. B. Ross, D. R. Davies, and A. E. Brooks. 2003. Effect of Lactobacillus buchneri, Lactobacillus fermentum, or Leuconostoc mesenteroides inoculants or a chemical additive on the fermentation, aerobic stability, and nutritive value of crimped wheat grains. J. Dairy Sci. 86:1789-1796.

Bach, S. J., T. A. McAllister, J. Baah, L. J. Yanke, D. M. Veira, V. P. J. Gannon, and R. A. Holley. 2002. Persistence of Escherichia coli O157:H7 in barley silage: Effect of a bacterial inoculant. J. Appl. Microbiol. 93:288-294.

Benjamin, M. M., and A. R. Datta. 1995. Acid tolerance of enterohemorrhagic Escherichia coli. Appl. Environ. Microbiol. 61:1669-1672. 
Byrne, C. M., P. O'Kiely, D. J. Bolton, J. J. Sheridan, D. A. McDowell, and I. S. Blair. 2002. Fate of Escherichia coli O157:H7 during silage fermentation. J. Food Prot. 65:1854-1860.

Chapman, P. A., C. A. Siddons, A. T. Cerdan Malo, and M. A. Harkin. 1997. A 1-year study of Escherichia coli O157 in cattle, sheep, pigs and poultry. Epidemiol. Infect. 119:245-250.

Chen, Y., S. Sela, M. Gamburg, R. Pinto, and Z. G. Weinberg. 2005. Fate of Escherichia coli during ensiling of wheat and corn. Appl. Environ. Microbiol. 71:5163-5170.

Driehuis, F., S. J. W. H. Oude Elferink, and P. G. Van Wikselaar. 2001. Fermentation characteristics and aerobic stability of grass silage inoculated with Lactobacillus buchneri, with or without homofermentative lactic acid bacteria. Grass Forage Sci. 56:330343.

Fenlon, D. R., and J. Wilson. 2000. Growth of Escherichia coli O157 in poorly fermented laboratory silage: A possible environmental dimension in the epidemiology of E. coli O157. Lett. Appl. Microbiol. 30:118-121.

Filya, I. 2003. The effect of Lactobacillus buchneri and Lactobacillus plantarum on the fermentation, aerobic stability, and ruminal degradability of low dry matter corn and sorghum silages. J. Dairy Sci. 86:3575-3581.

Gollop, N., V. Zakin, and Z. G. Weinberg. 2005. Antibacterial activity of lactic acid bacteria included in inoculants for silage and in silages treated with these inoculants. J. Appl. Microbiol. 98:662-666.

Huisden, C. M., A. T. Adesogan, S. C. Kim, and T. Ososanya. 2009. Effect of applying molasses or inoculants containing homofermentative or heterofermentative bacteria at two rates on the fermentation and aerobic stability of corn silage. J. Dairy Sci. 92:690-697.

Jack, R. W., J. R. Tagg, and B. Ray. 1995. Bacteriocins of grampositive bacteria. Microbiol. Rev. 59:171-200.

Kleinschmit, D. H., R. J. Schmidt, and L. Kung Jr.. 2005. The effects of various antifungal additives on the fermentation and aerobic stability of corn silage. J. Dairy Sci. 88:2130-2139.

Lynn, T. V., D. D. Hancock, T. E. Besser, J. H. Harrison, D. H Rice, N. T. Stewart, and L. L. Rowan. 1998. The occurrence and replication of Escherichia coli in cattle feeds. J. Dairy Sci 81:1102-1108.

Mechie, S. C., P. A. Chapman, and C. A. Siddons. 1997. A fifteen month study of Escherichia coli O157:H7 in a dairy herd. Epidemiol. Infect. 118(Suppl.1):17-25.

Meile, L., G. Dasen, S. Miescher, M. Stierli, and M. Teuber. 1999 Classification of propionic acid bacteria and approaches to applied genetics. Lait 79:71-78.

Merry, R. J., and D. R. Davies. 1999. Propionibacteria and their role in the biological control of aerobic spoilage in silage. Lait 79:149164.

Muck, R. E., and J. T. Dickerson. 1988. Storage temperature effects on proteolysis in alfalfa silage. Trans. ASAE 31:1005-1009.

Ranjit, N. K., C. C. Taylor, and L. Kung Jr.. 2002. Effect of Lactobacillus buchneri 40788 on the fermentation, aerobic stability and nutritive value of maize silage. Grass Forage Sci. 57:73-81.

Riley, L. W., R. S. Remis, S. D. Helgerson, H. B. McGee, J. G. Wells, B. R. Davis, R. J. Hebert, E. S. Olcott, L. M. Johnson, N. T. Hargrett, P. A. Blake, and M. L. Cohen. 1983. Hemorrhagic colitis associated with a rare Escherichia coli serotype. N. Engl. J. Med. 308:681-685.

Taylor, C. C., N. J. Ranjit, J. A. Mills, J. M. Neylon, and L. Kung Jr. 2002. The effect of treating whole-plant barley with Lactobacillus buchneri 40788 on silage fermentation, aerobic stability, and nutritive value for dairy cows. J. Dairy Sci. 85:1793-1800.

Weinberg, Z. G., G. Ashbell, Y. Chen, M. Gamburg, and S. Sela. 2004. The effect of sewage irrigation on safety and hygiene of forage crops and silage. Anim. Feed Sci. Technol. 116:271-280.

Weinberg, Z. G.. G. Ashbell, Y. Hen, A. Azrieli, G. Szakacs, and I. Filya. 2002. Ensiling whole-crop wheat and corn in large containers with Lactobacillus plantarum and Lactobacillus buchneri. J. Ind. Microbiol. Biotechnol. 28:7-11.

Woolford, M. K. 1975. Microbial screening of food preservatives, cold sterilants, and specific antimicrobial agents as potential silage additives. J. Sci. Food Agric. 26:229-237. 